Ital.J.Geosci. (Boll.Soc.Geol.It.), Vol. 129, No. 1 (2010), pp. 51-68, 12 figs. 1 pl. f.t. (DOI:

10.3301/IJG.2009.04)

\title{
Structural and petrographic analysis at the north-eastern margin of the Oligocene Traversella pluton (Internal Western Alps, Italy)
}

\section{DAVIDE ZANONI $(*)$}

(*) Dipartimento di Scienze della Terra «A. Desio», via Mangiagalli, 34 - 20133 Milano, Italy. Present address: Department of Geology, University of New Brunswick, 2 Bailey Drive, Fredericton, NB, Canada E3B 5A3; dzanoni@unb.ca

\section{ABSTRACT}

In this work a new form surface map at 1:5000 scale of the north-eastern margin of the Oligocene Traversella pluton, synthesised from a field structural study assisted by optical petrography, is presented. Relative chronology of superposed foliations and effects of progress of contact metamorphic reactions in the contact aureole are shown on the structural map for each of the country rock-types of the Sesia-Lanzo Zone. The structural and metamorphic evolution was reconstructed across the north-eastern margin of the pluton by separating the pre- and the post-intrusive tectonic history and defining the contact aureole outline. Contact metamorphic assemblages and thermobarometric estimates indicate that this intrusive body emplaced at shallow structural levels (contact metamorphism peak conditions: $\mathrm{T}<750^{\circ} \mathrm{C} ; \mathrm{P}<0.2$ $\mathrm{GPa})$.

KEY WORDS: Form surface map, contact metamorphism, Traversella pluton, Sesia-Lanzo Zone, Western Alps.

\section{RIASSUNTO}

Analisi strutturale e petrografica del margine nord-orientale del plutone oligocenico di Traversella (Alpi Occidentali Interne, Italia).

Questo lavoro presenta una nuova carta delle traiettorie delle foliazioni, in scala 1:5000, sintetizzata da un rilevamento strutturale e petrografico del margine nord orientale del plutone di Traversella, appoggiato all'analisi microscopica. II plutone di Traversella (VAN MERKE DE LUMMEN \& VANDER AUWERA, 1990), appartenente all'insieme dei plutoni periadriatici e con età radiometrica attorno ai $30 \mathrm{Ma}$ (KRUMMENACHER \& EVERNDEN, 1960), è intruso nella parte più interna della Zona Sesia-Lanzo (Austroalpino Occidentale). Il distacco della radice litosferica durante la collisione alpina, è considerato I'innesco per il magmatismo periadriatico (VON BLANCKENBURG \& DAVIES, 1995). La perturbazione termica prodottasi di conseguenza, avrebbe permesso la fusione parziale della base del mantello litosferico sottocontinentale e la generazione di magmi, contaminati poi da materiali crostali, che costituiscono la sorgente del magmatismo periadriatico (VON BLANCKENBURG et alii, 1998). L'insieme delle faglie crostali interne delle Alpi, dal Canavese alla Pusteria, è stato considerato la via di risalita dei magmi periadriatici attraverso la crosta continentale ispessita durante l'orogenesi alpina (ROSENBERG, 2004). Le ricostruzioni dell'evoluzione tettono-metamorfica (e.g. POGNANTE, 1989; SPALLA et alii, 1996; ZUCALI et alii, 2002) indicano che la Zona Sesia-Lanzo ha seguito un percorso di esumazione in un regime termico depresso, realizzabile in contesti geodinamici in cui la subduzione di litosfera oceanica è attiva. L'Unità dei Micascisti 
Eclogitici (e.g. COMPAGNONI et alii, 1977), che costituisce la parte più interna della Zona Sesia-Lanzo, registra durante la convergenza alpina un'impronta metamorfica dominante in facies eclogitica (e.g. POGNANTE, 1989; ZUCALI et alii, 2002), con età radiometrica cretaceo-paleocenica (e.g. OBERHÄNSLI et alii, 1985; INGER et alii, 1996; DUCHENE et alii, 1997; RUBATTO et alii, 1999; RUFFET et alii, 1997). II margine nord orientale del plutone di Traversella è costituito principalmente da dioriti e monzodioriti che mostrano una foliazione magmatica, mentre le rocce incassanti sono costituite principalmente da metapeliti, metaapliti e ortogneiss che registrano cinque stadi di deformazione duttile. I primi tre gruppi di strutture (D1, D2 e D3) sono coevi con le associazioni di minerali di alta pressione e bassa temperatura, mentre il quarto gruppo (D4) è coevo alla riequilibrazione regionale in facies scisti verdi. Durante lo sviluppo del quinto gruppo (D5) i minerali di facies scisti verdi sono soggetti a ricristallizzazione dinamica. La messa in posto del plutone è successiva alla deformazione duttile polifasica delle rocce incassanti. Sia le rocce plutoniche, che quelle incassanti, possiedono fino a quattro gruppi di strutture fragili, di cui il secondo viene qui associato alla deformazione fragile lungo la linea del Canavese. Strutture fragili mineralizzate e un gruppo di fratture a basso angolo nel plutone sono interpretate come dovute al raffreddamento. Nel basamento incassante le fratture radiali rispetto al margine del plutone sono interpretate come strutture causate dalla spinta magmatica durante la messa in posto. Nella carta geologica allegata sono rappresentati, per ogni litotipo delle rocce incassanti, diversi gradi di trasformazione per metamorfismo di contatto, definiti sulla base delle percentuali in volume dei minerali caratteristici del metamorfismo di contatto. A ciò è stato correlato lo schema interpretativo della cronologia relativa delle foliazioni integrato alla storia metamorfica. I diversi gradi di trasformazione per metamorfismo di contatto rappresentati in carta evidenziano l'irregolarità dell'estensione dell'aureola metamorfica, controllata probabilmente dalla differente permeabilità dei litotipi incassanti, dal contenuto in fasi più suscettibili al metamorfismo di contatto e dalle relazioni di orientazione tra le foliazioni dell'incassante e il margine del plutone. L'analisi microstrutturale delle rocce magmatiche ha permesso di dedurre una sequenza di cristallizzazione delle fasi magmatiche e di individuare le ricristallizzazioni in sub-solidus. Poiché il plutone interseca le strutture D4, marcate da minerali caratteristici della facies scisti verdi, coeve con l'esumazione del complesso eclogitico incassante, si possono ipotizzare livelli crostali di intrusione non più profondi di quelli corrispondenti al campo P-T di questa facies metamorfica (condizioni di picco del metamorfismo di contatto: $T<750^{\circ} \mathrm{C} ; \mathrm{P}<0.2 \mathrm{GPa}$ ), in accordo con la letteratura e con le associazioni di minerali di contatto dedotti dall'analisi micro strutturale e con le stime termobarometriche. L'età radiometrica di circa $40 \mathrm{Ma}$, proposta per l'esumazione a condizioni di scisti verdi della parte più esterna della Zona Sesia-Lanzo (INGER et alii, 1996; CORTIANA et alii, 1998) supporterebbe il raggiungimento di livelli strutturali superficiali delle rocce incassanti prima della messa in posto del plutone (30 Ma).

TERMINI CHIAVE: Carta delle traiettorie delle foliazioni, metamorfismo di contatto, plutone di Traversella, Zona Sesia-Lanzo, Alpi Occidentali.

\section{INTRODUCTION}

Within the Western Alps two km-sized plutons (Biella and Traversella) and andesitic dykes and lava flows are part of the Oligocene igneous rocks, which are wide-spread along the Periadriatic line, named Canavese line along its western north-south trending portion. The intrusion of these igneous rocks in the pre-Alpine continental metamorphic basement of the Sesia-Lanzo Zone postdates the Alpine eclogite facies metamorphism, which is dominant in the country rocks. The absolute age of the eclogite facies metamorphism is known as well as that one of the Oligocene magmatism. This work infers the structural and metamorphic evolution in the region close to the north-eastern Traversella pluton margin, which 
comprises the contact aureole, the emplacement structural level, and the final exhumation path of the Sesia-Lanzo Zone.

\section{GEOLOGICAL SETTING}

The Sesia-Lanzo Zone records a pervasive Alpine HP-LT metamorphism and belongs to the Austroalpine Domain of the Western Alps (fig. 1a), which is interpreted as a part of the Adria active continental margin (e.g. POLINO et alii, 1990). Mylonites developed under eclogite or blueschist facies conditions (LARDEAUX et alii, 1982; POGNANTE et alii, 1987) and later under greenschist facies conditions (RIDLEY, 1989; STÜNITZ, 1989; SPALLA et alii, 1991), separate the Sesia-Lanzo Zone in two tectonic units (fig. 1b), which are characterised by different lithology and dominant metamorphic imprint (e.g. COMPAGNONI et alii, 1977). The upper unit (II Dioritic Kinzigitic Zone) consists of metapelites and metabasics with a dominant metamorphic imprint under amphibolite to granulite facies conditions of pre-Alpine age. The lower unit consists of metapelites, metabasics, and metagranitoids (partly deriving from Early Permian intrusives: OBERHÄNSLI et alii, 1985; BUSSY et alii, 1998), which belong to two metamorphic complexes that preserve an Alpine pervasive metamorphic imprint: the Gneiss Minuti Complex (GMC) and the Eclogitic Micaschist Complex (EMC).

The dominant metamorphic imprint is characteristic of greenschist and eclogite facies conditions respectively in the GMC in the EMC. In the latter the eclogite pervasive imprint predates blueschist reequilibration related to decompression (CASTELLI, 1991; POGNANTE, 1991; ZUCALI et alii, 2002) and greenschist re-equilibration, which took place locally within shear zones developed during the final stages of exhumation (e.g. HANDY et alii, 2005). Radiometric data obtained on eclogite minerals are scattered between Late Cretaceous and Early Palaeocene (e.g. OBERHÄNSLI et alii, 1985; INGER et alii, 1996; DUCHENE et alii, 1997; RUFFET et alii, 1997; RUBATTO et alii, 1999).

In the Sesia-Lanzo Zone up to six structural and metamorphic re-equilibrations stages have been described

(GOSSO, 1977; POGNANTE et alii, 1980; PASSCHIER et alii, 1981; SPALLA et alii, 1983; WILLIAMS \& COMPAGNONI, 1983; STÜNITZ, 1989; ILDEFONSE et alii, 1990; LARDEAUX \& SPALLA, 1991; VENTURINI et alii, 1991; INGER \& RAMSBOTHAM, 1997; ZUCALI et alii, 2002). The earlier structures are coeval with preAlpine granulite to amphibolite facies metamorphism and are related to Permian-Triassic extension of the Adriatic lower continental crust (e.g. LARDEAUX \& SPALLA, 1991; REBAY \& SPALLA, 2001). The successive structures are coeval with the Alpine subduction, which leads to blueschist and eclogite facies conditions metamorphism. The thermo-barometric history inferred in the Sesia-Lanzo Zone (e.g. POGNANTE, 1989; ZUCALI et alii, 2002) highlights a prograde and retrograde metamorphic evolution under depressed geothermal gradients, which suggest that the oceanic subduction was still going on at the times of the exhumation of this tectonic unit (SPALLA et alii, 1996). This agrees with absolute age data, which indicate that between 50 and 40 Ma oceanic crust was still being eclogitised (DUCHE`NE et alii, 1997; AMATO et alii, 1999; CLIFF et alii, 1998; DESMONS et alii, 1999; DAL PIAZ et alii, 2001) and between 45 and 37 Ma the outer part of the Sesia-Lanzo Zone (GMC) recorded greenschists re-equilibration during the final stages of its exhumation (INGER et alii, 1996; CORTIANA et alii, 1998).

The Tertiary Biella and Traversella plutons (fig. 1b) and andesitic dykes intruded the innermost part of the Sesia-Lanzo Zone (EMC) (e.g. DE CAPITANI et alii, 1979; BECCALUVA et alii, 1983). Such igneous bodies belong to the orogen scale Periadriatic magmatism (e.g. BECCALUVA et alii, 1983; ROSENBERG, 2004), which has been dated around $30 \mathrm{Ma}$ in the Western Alps (KRUMMENACHER \& EVERNDEN, 1960; BIGIOGGERO et alii, 1994; ROMER et alii, 1996) and displays a calcalcaline to shoshonitic signature 
(BIGIOGGERO et alii, 1994; DUBRU et alii, 1988; CALLEGARI et alii, 2004). As in the rest of the Periadriatic magmatic province, the parent magmas likely derived from the partial melting of the Adria lithospheric mantle (VON BLANCKENBURG et alii, 1998), induced by astenosphere upwelling as a consequence of the slab break off, which postdated the end of the oceanic subduction of some million years (VON BLANCKENBURG \& DAVIES, 1995).

The Periadriatic line was a weak crustal zone which may have constituted the preferential ascent path through the Alpine belt for these magmas; magma ascent has been interpreted as coeval and controlled by mylonitic deformation within this line (ROSENBERG, 2004; HANDY et alii, 2005). According to these authors such main crustal break has been formed by contrasting rheology between the uprising hotter and more ductile Austroalpine and Penninic nappes on the northern side and the colder and more brittle rocks of the Southalpine Domain on the southern side. Within the framework of the Periadriatic magmatism the Traversella pluton represents the westernmost outcropping igneous body. The emplacement of this pluton, which mainly consists of diorites, minor enclaves of mafic cumulates, and later granitic veins (VAN MERKE DE LUMMEN \& VANDER AUWERA, 1990), took place by consecutive intrusive stages (VANDER AUWERA, 1990).

\section{ROCK TYPES}

The country rocks (Sesia-Lanzo Zone) at the northeastern margin of the Traversella pluton consist of metapelites and interlayered meta-aplites and metagranitoids. Mainly diorites and minor monzodiorites and andesites constitute the Tertiary igneous rocks.

\section{COUNTRY ROCKS OF THE TRAVERSELLA PLUTON}

In the study area the country rocks mainly consist of metapelites, meta-aplites, and fine-grained metagranitoids. Metapelites consist of micaschists grading to paragneisses, in which the pervasive foliation is marked by Qtz- rich lithon and Wm-rich films and locally also by transposed meta-aplitic dykes. Grt and Omp form up to cmsized porphyroclasts. Locally $\mathrm{dm}$-sized rounded aggregates mainly containing Qtz and $\mathrm{Pl}$, interpreted as retrogressed Jd megablasts (ANDREOLI et alii, 1976), occur. The pervasive foliation (S2 in the following chapter) wraps rare metabasic lenses.

Coarse-grained meta-aplites outcrop mainly at Le Colme (plate I); in these rocks Qtz ribbons, Wm, and Kfs mark the pervasive foliation. Fine-grained metagranitoids outcrop mainly between Gr. Verna and Tirovana (plate I); rarely coarse-grained metagranitoids occur. The greenish colour of these rocks, which contain rare Wm and Grt, suggests abundance of Omp.

The effects of contact metamorphism gradually increase towards the pluton margin and comprise the decrease of Wm modal amount, formation of Bt-rich aggregates, and increase of polygonal texture in Qtzaggregates.

These mineral replacements also correspond to a marked change in the country rocks fabric, which becomes granoblastic.

\section{IGNEOUS ROCKS OF THE TRAVERSELLA PLUTON}

Diorites and monzodiorites mainly constitute this part of the Traversella pluton margin; in these rocks changes from coarse to fine grain size are gradual. North of Caras (plate I) a diorite bearing apophysis shows a coarser grain. Rare metamorphic xenoliths occur only close to the country rocks; their shape is 
elongated with smoothed edges and they preserve a foliation marked by Bt- and Qtz-feldspar-rich layers. From $\mathrm{cm}$ - to $10 \mathrm{~cm}$-thick leucocratic dykes intrude the diorite (fig. 2a) and from $10 \mathrm{~cm}$ - to m-thick andesitic dykes intrude the country rocks and are discordant with respect to the pervasive foliation ( $\mathrm{S} 2$ in the following chapter) (fig. 2b).

\section{STRUCTURAL ANALYSIS}

The country rocks record five groups of ductile superposed structures (D1, D2, D3, D4, D5) and four groups of brittle structures (B1, B2, B3, B4). Differently from the ductile structures, generally most of the brittle structures affect both plutonic and country rocks.

\section{DUCTILE DEFORMATION}

D1 comprises $\mathrm{S} 1$ foliation that is preserved in metapelites and meta-aplites and is marked by minerals characteristic of eclogite facies. Locally S1 marks the boundary between mepelites and meta-aplites (fig. 3a). S1 is deformed by F2 folds and dips with angles between $25^{\circ}$ and $60^{\circ}$ towards the SSW, SSE and, NE (fig. 4).

D2 is mainly constituted by tight to isoclinal F2 folds associated with a S2 foliation. Minerals characteristic of eclogite facies mark $\mathbf{2}$, which is the pervasive foliation in all lithotypes of the country rocks. In metapelites up to $\mathrm{m}$-sized meta-aplitic dykes are locally transposed into parallelism with $\mathrm{S} 2$ and, both in metapelites and in finegrained metagranitoids; $\mathrm{S} 2$ is also marked by up to m-sized Qtz-layers. S2 is mainly a continuous foliation and $\mathrm{S} 1$ is better preserved only where $\mathrm{S} 2$ is a spaced foliation. Locally D2 forms a mylonitic foliation, s-c structures (fig. 3b), and low-angle extensional lineation (between Capannette and C. Pratorotondo). The most of S2 poles matches with S1 poles, which dip towards the SSE and SSW (fig. 4); this may suggest that SSE- and SSW-dipping S1 poles represent the limbs of F2 isoclinal folds approaching S2, while $\mathrm{S} 1$ poles dipping towards the NE may represent the hinge zones of the most open F2 folds. The good overlap of S2 and AP2 poles (fig. 4) is coherent with the isoclinal geometry of the F2 folds. Generally the S2 foliation and F2 axial planes dip towards the SW, S, and SE with an angle of $20-40^{\circ}$. In the Piano Verna area S2 dips mainly towards the $S$ with angles between $15-50^{\circ}$, in the area of Casebelle it dips mainly towards the SW with angles between $20-60^{\circ}$, and in the M. Gregorio area it dips towards the S with angles between $35-60^{\circ}$ (fig. 5). A2 axis plunge with angles between few degrees and $40^{\circ}$ (fig. 4).

D3 comprises small-scale ductile dextral shear zones, which intersect S2. These structures dip towards the SW or SE at a high angle (fig. 4). Intersection relationships between these shear zones and the D4 structures have not been observed, but these shear zones may be the analogous of the blueschist shear zones of the M. Mucrone area (ZUCALI et alii, 2002).

D4 comprises F4 folds and a rare spaced S4 crenulation cleavage. From $\mathrm{m}$ - to $10 \mathrm{~m}$-sized $\mathrm{F} 4$ folds have axial plane dipping $10-40^{\circ}$ and axes plunging $5-25^{\circ}$ (fig. 4). Generally asymmetric F4 folds have rounded hinges (fig. 3c), but locally symmetric F4 folds (like south east of Gr. Verna or south of F. dell'Acquabella; see plate I) may represent hinge zones of larger-scale structures. S4 develops only in metapelites (like south of $\mathrm{M}$. Gregorio or south-est of Gr. Piani; see plate I), dips $20-40^{\circ}$ towards the N or S (fig. 4) and is marked by Wm and Chl.

D5 comprises F5 m-sized open folds with sub-vertical axial plane and sub-horizontal axis (figs. 3d, 4). Only locally F5 fold are cm-sized. The similar orientation of F4, F5, and S4 poles in the three sub-area shown in fig. 5 suggests that the variation of the $\mathrm{S} 2$ orientation is due to these folding stages and not by displacement along faults. In the three sub-areas, the distribution of the S2 poles seems to reproduce at a 
larger scale the shape of the F4 folds that are mostly responsible for the orientation of S2, also according to the gentle shapes of the F5 folds. Therefore during the rotation of the innermost part of the Sesia-Lanzo Zone, indicated by the analysis of the magnetic lineation in andesites (LANZA, 1984), rocks of this area should have behaved rigidly.

A sub-vertical magmatic foliation $(\mathrm{Sm})$ is recorded in the intrusive rocks of the Traversella pluton. Generally this foliation is parallel to the margin with the country rock and this suggests that the geometry of the margin may have driven the magmatic flow and that the intrusion did not cause ductile deformation in the country rock. The contact with the country rock is either sharp or irregular and, as it is evident in the Assa stream, magma intruded along the S2 surfaces. The pluton margin generally is discordant with respect to the S2 foliation and in particular crosscuts the F4 folds. The orientation of S2 is sensibly different that that one of Sm, suggesting that the intrusion postdate even the F5 folds (plate I).

\section{BRITTLE DEFORMATION}

Four generations of brittle deformations, generally recorded both in the basement and in the plutonic rocks, are evident in the eastern portion of the Traversella pluton on the ground of overprinting relationships.

B1 consists of fractures dipping $60-70^{\circ}$ mainly towards the SE and ENE and from ductile to brittle dextral shear zones in fine grained metagranitoids between Gr. Piani and Gr. Verna (fig. 6a). In diorites at Piano Verna a cataclastic band shows a compatible orientation with B1 fractures and east of F. Acquarossa and close to Gr. Doglia rare cataclastic bands mimic the $\mathrm{S} 2$ foliation (fig. $6 \mathrm{~b}$ ). The relationships among these cataclastic bands and B1 structures are not clear. B1 structures are more frequent in country rocks rather than in plutonic rocks (fig. 7) and this may suggest that the stress field responsible for these structures was already active before or during the intrusion. B2 is constituted by fractures dipping 50-70 towards NW in the country rocks and in the plutonic rocks, even according with evidences in single outcrops continuous from plutonic to country rocks. In the diorite west of Gr. Doglia a normal fault plane with dextral slip component is oriented coherently with B2 fractures. B2 are the most frequent and persistent fractures (figs. 6c, 7) and overprint the B1 cataclastic bands parallel to the S2 foliation.

B2 structures display similar frequency in the pluton and in the country rock; their orientation is similar to that of the Canavese line and may be associated to a brittle pulse of this main fault.

B3 is a set of fractures dipping $50-70^{\circ}$ towards the SW (fig. 7) and by small sinistral fault planes locally with inverse component as for instance close to top of M. Gregorio and Gr. Piani. A normal fault and a normal dextral fault, with orientation compatible to this group of structures, respectively occur in M. Gregorio locality and in the diorite north of Piano Verna.

B4 is constituted by poorly persistent outcrop scale fractures dipping towards the ENE (fig. 7). In addition to these four groups of structures low-angle cm-spaced fractures with smoothed surface (figs. 6d, 7) are concentrated in plutonic rocks; they may be due to magma cooling (KANO \& TSUCHIYA, 2002). In the Brosso quarry $\mathrm{mm}$-sized ductile/brittle deformation bands are localized along these fractures. Sub-vertical cooling fractures intersect only the diorite (fig. 6e). Chl- and rare Ep-Chl-bearing fractures intersect plutonic rocks (fig. 8): their orientation is similar to that of the leucocratic dykes intruding plutonic rocks (fig. 8) and locally is coherent with the orientation of B2 structures. In the Piano Verna area the Chl-bearing fractures are parallel to the magmatic foliation. Both mineralised fractures and leucocratic dykes show a suborthogonal orientation to the margin of the pluton (fig. 8). These featuressuggest that also the mineralised 
fractures may be due to magma cooling (SEGALL \& POLLARD, 1983; BERGBAUER \& MARTEL, 1999; ROMA'N-BERDIEL \& PUEYO-MORER, 2000; KOENDERS \& PETFORD, 2003).

In proximity of the Brosso mine (Miniere di Pirite in plate I) S2 is intersected by rare Tur-bearing fractures. Also, S2 is intersected by cm-thick fractures filled by Qtz and minor feldspar (fig. 6f); the orientation of most of these fractures is coherent with the orientation of $\mathrm{B} 2$ structures, but is also always sub-orthogonal to the pluton margin (fig. 8). These fractures may have formed for magma pushing during the intrusion.

In conclusion the enclosed map displays the analytical results of mesoscopic studies of the structures carried out during mapping. It shows lithostructural relationships and chronologically distinct foliation trajectories and it is meant here to be self explaining. The reader is addressed to the details of the legend, that includes information on the microstructural history. Meso- and megascopic fold implications between the country rocks are illustrated on the cross section grid, side of the structural map. They originated during the Alpine tectonic history deep in the orogenised crust, or even deeper in the lithosphere, during subduction and exhumation. In these processes the pre-orogenic lithostratigraphy was deformed by tectonic transposition mechanisms and transformed into a new tectonostratigraphic sequence, as for instance shown in cross sections $A-A^{\prime}$ and $B-B^{\prime}$.

Along cross section C-C' the huge implication of igneous within country rocks, evident at A-A' and B-B' intersections, is interpreted as a later nearly horizontal pluton apophysis, of intrusive shape, poorly modified in its configuration after intrusion.

\section{MICROSTRUCTURAL ANALYSIS}

The microstructural analysis of country rocks is aimed to the comprehension of the timing of mineral growth with respect to the deformation history and to the individuation of the relative chorology between regional scale ductile deformation and growth of contact metamorphic mineral phases (VERNON, 2004; PASSCHIER \& TROUW, 2005). For this purpose the analytical techniques to unravel mineral reactions in coronitic structures have been taken into account. Microstructural analyses in igneous rocks utilises detection criteria of the order of crystallisation of magmatic phases and the type of deformation (PATERSON et alii, 1989; VERNON, 2004).

\section{TEXTURE AND METAMORPHISM OF THE COUNTRY ROCKS}

The synergy between the meso- and micro-structural analyses of the country rocks of the Traversella pluton allowed to distinguish, in each rock type, different degrees of transformation consequent to contact metamorphism, which are reported on the attached geological map (plate I). The map locates therefore rocks unaffected by contact metamorphism, slightly transformed rocks ( $\leq 30 \%$ modal amount of contact minerals), transformed rocks ( $\leq 60 \%$ modal amount of contact minerals), and fully transformed rocks ( $\geq$ $60 \%$ modal amount of contact minerals) during contact metamorphism. The amount of preserved minerals characteristic of the HP and greenschist facies regional metamorphic imprints increases with the distance from the pluton. Even where intense recrystallisation generated a granoblastic structure, ghost foliation traces are still mesoscopically visible.

\section{Metapelites}

In metapelites quartz (Qtz)-rich layers and SPO and LPO of white mica (WmII) mark S2. Omphacite (Omp) and amphibole (Ampll; $\mathrm{Hbl}$ and $\mathrm{Gln}$ ) show SPO parallel to S2; only locally Ampl is oblique to $\mathrm{S2}$. WmI marks folded relict of $\mathrm{S} 1$ preserved between $\mathrm{S} 2$ films and forms single relict crystals traversal to $\mathrm{S} 2$, which are 
internally more deformed than Wmll. Perthitic K-feldspars (Kfs) and garnet (Grt) are wrapped by S2; Grt shows rational rim against Wmll. Mica-fishes, s-c structures, and obliquity of a Qtz-ribbon foliation characterise the mylonitic S2. Rare epidote (Epl; zoisite) shows SPO parallel to S2, locally contains Rt crystals, and is rimmed by Epll (with high interference colour). SPO and LPO of Qtz, chlorite (ChII) and WmIII mark S4 axial plane foliation. Chll fills also the boudin neck of Ampll and the Grt fractures, rims Omp, Wml, and WmII, and forms rosetta aggregates, which overgrew S2. AmpIII and Ab grew in the boudin necks of Omp.

Between 100 and $240 \mathrm{~m}$ (in plan view) from the pluton margin, metapelites contain up to $30 \%$ of contact metamorphic minerals. Thin Bt and PI coronas rim Wml and Wmll; Bt mimics Wml and WmII. Pre-contact metamorphism Amp is still preserved. Green Bt and minor PI form fine-grained coronas on Grt. In rich-Qtz layer only the smaller crystals are recrystallised. Very fine-grained aggregates of $\mathrm{Bt}, \mathrm{Ab}, \mathrm{Qtz}$, and minor Kfsll replace Omp. PI forms polygonal aggregates of $\mu \mathrm{m}$-sized crystals.

Between 60 and $200 \mathrm{~m}$, in plan view, from the pluton margin the country rock contains up to $60 \%$ of contact metamorphic phases and Qtz grains are slightly recrystallised. Wml, Wmll, and Grt are still well preserved. Fine grained symplectites of $\mathrm{Bt}$ and $\mathrm{PI}$ or $\mathrm{PI}$ and AmpIV replace Omp, of which the core is occasionally preserved. Glaucophane (GIn) is partially replaced by WmIV and PI. Locally between WmII and Grt fine-grained symplectites of Bt and PI developed (fig. 9a). IIm rims titanite (Ttn) and rutile (Rt).

Closer to the pluton margin metapelites contain more than $60 \%$ of contact metamorphic minerals. Wml and WmIl porphyroclasts are rarely preserved. Bt increases in quantity and size. Mostly deformation-free Qtz grains form layers of inequigranular polygonal aggregates. At about $10 \mathrm{~m}$ from the pluton polygonal structures are fully developed. Epl, Epll, Kfsl, Ttn, and Grt are still locally preserved. REE-rich EpIII rims EpI and Epll. Rounded aggregates of Bt containing IIm may have fully replaced Grt, which, in Qtz-rich layers, is replaced by fine-grained $\mathrm{Bt}$ and $\mathrm{Pl}$ aggregates. $\mathrm{WmI}$ and $\mathrm{Wmll}$ are fully replaced by symplectites of $\mathrm{Pl}$ and $\mathrm{Bt}$ with minor corundum ( $\mathrm{Crn}$ ) and KfsIl. Mainly PI and Bt replace probable Gln (fig. 9b), which is rimmed by Kfsll and Qtz (fig. 9b) as well as Wm. Bt, $\mathrm{Pl}$, and minor Qtz symplectites and rare AmplV fully replace Omp. Locally Kfsll forms fine-grained aggregates parallel to $\mathrm{S} 2$. At about $10 \mathrm{~m}$ from the pluton also spinel (Sp) replaces Wm. Red Bt forms also mm-sized euhedral crystals, which often contain globular Ilm. Polygonal Qtz and PI layers occur. Even close to the margin, Chll is only partially rimmed by Bt. Locally Wm is replaced by $\mathrm{Bt}$ and $\mathrm{PI}$ that are respectively more and less abundant in the core of these porphyroclasts. At a few centimetres from the pluton margin $\mathrm{Wm}$ is fully replaced by $\mathrm{Bt}, \mathrm{PI}, \mathrm{Sp}$, and cordierite (Crd) (fig. 9c). Locally at the pluton margin ( $200 \mathrm{~m}$ east of Baita le Colme and east of Fontana dell'Acquabella in plate I) layers of rounded Qtz crystals are both parallel and transversal with respect to S2 foliation. KfsIl (fig. 9d) and PI interstitially crystallised between these Qtz grains, which are locally in contact with euhedral Crd crystals (fig. 9e). These features suggest that partial melting of metapelites may have taken place (e.g.: STEVENS et alii, 1997; ROSENBERG \& RILLER, 2000) and the euhedral Crd crystals may represent the peritectic phase (e.g.: STEVENS et alii, 1997; JUNG et alii, 2000; VERNON, 2004). Chlll forms fine-grained crystals replacing the contact metamorphism symplectites. Fine grained WmV coronas developed at the Sp and Crn rim; WmV and Chlll mimetically grew also on Bt (fig. 9f). Green Bt partially replace red Bt.

Meta-aplites

S2 foliation is a spaced cleavage, locally discontinuous, marked by Qtz-rich layers, SPO and LPO of mm-sized WmIl, and by SPO of KfsI porphyroclasts. KfsI shows deformation twinning and Ab lamellae. Locally SPO of Qtz crystals form an oblique foliation, but generally grains show undulose extinction and form interlobated inequigranular aggregates. $\mathrm{Wml}$ is transversal with respect to $\mathrm{S2}$, is more deformed than $\mathrm{WmIl}$, and marks 
S1 folded foliation preserved between S2 films. Up to cm-sized Grt locally occurs within Qtz layers. Ab shows an internal foliation marked by WmIl, which is parallel and continuous with respect to the external foliation; fine-grained WmIII aggregates grew at the expenses of the Kfsl. Where country rocks contain less than modal $60 \%$ of contact metamorphic phases $\mathrm{Wml}$ and $\mathrm{Wmll}$ are replaced by very fine-grained mimetic crystals of Bt. In Qtz-rich layers fine-grained crystals show scarce internal deformation and near-polygonal structures. Where country rocks contain more than modal $60 \%$ of contact metamorphism minerals Wml and $\mathrm{WmIl}$ are fully replaced by $\mathrm{PI}, \mathrm{Bt}, \mathrm{Sp}$, and minor $\mathrm{Crd}$ or by $\mathrm{PI}, \mathrm{Kfsll}, \mathrm{Bt}$, and $\mathrm{Sp}$ (fig. 10a). PI, KfsIl, and Bt form mimetic aggregates on Wm. Layers of new grains of $\mathrm{Kfsll}$ developed parallel to $\mathrm{S} 2$. KfsI and Grt are still well preserved. In Qtz-rich layers polygonal aggregates of deformation-free grains

\section{Metagranitoids}

In coarse- to fine-grained metagranitoids, S2 foliation is marked by SPO of WmIl and by Qtz-rich layers made of internally deformed grains. Wmll is more abundant in coarse-grained rocks and marks a spaced and discrete S2 foliation. Epl, Ttnl, Rt, and porphyroclasts of Omp and Kfsl are parallel to S2; Epll rims Epl. Grt is wrapped by S2 films or forms euhedral grains enclosed in Omp. Grt shows also rational rims with Ttnl. Rare Wml and locally Epl are oblique to S2. Ap and rare Ampl are parallel to S2. Rare Chll is partially overgrown by Bt (fig. 10c) and fine-grained Ampll and PI fill veins intersecting S2 foliation.

Where rocks contain up to $30 \%$ of contact metamorphic minerals, Omp is fully replaced by fine-grained coronitic aggregates of KfsIl, AmpIII, and PI. Rare PI and Bt overgrew WmI, WmIl, and Grt; Bt grew also along Wm [001]. Ab films rim Wm and Omp porphyrocalsts. In Qtz-rich layers crystals show internal deformation. Ampl is partially replaced by AmpllI, Bt, and Kfsll (fig. 10d). At about $100 \mathrm{~m}$ far from the pluton margin, country rocks contain more than $60 \%$ of contact metamorphic minerals and consist of very fine-grained coronitic aggregates. PI forms granoblastic aggregates and $\mathrm{WmI}$ and $\mathrm{WmIl}$ are completely replaced by $\mathrm{Pl}, \mathrm{Bt}$, and $\mathrm{Crd}$. Locally Ep is still preserved. Ilm rims Ttnl. In Qtz-rich layers grains show a nearpolygonal structures. At about $45 \mathrm{~m}$ from the pluton margin $\mathrm{Grt}$ is rimmed by $\mathrm{Crd}, \mathrm{Pl}$, and $\mathrm{Bt}$ or by $\mathrm{Pl}, \mathrm{Bt}$, and rare Kfsll. Very fine-grained aggregates of $\mathrm{Pl}$, minor $\mathrm{Bt}$, and rare $\mathrm{Kfs}$ Il, replace Omp. At $20 \mathrm{~m}$ from the contact $\mathrm{WmI}$ and $\mathrm{WmIl}$ are fully replaced by $\mathrm{Sp}, \mathrm{Bt}, \mathrm{Pl}$, and $\mathrm{Crd}$ and are rimmed by Kfsll. Kfsll and $\mathrm{Pl}$ form polygonal granoblastic layers parallel to $\mathrm{S} 2$. Contact metamorphic phases are partially replaced by finegrained coronitic Chlll and TtnII. ChIII, opaque minerals, and rare WmIII mimetically replace Bt.

\section{Summary and interpretation of the country rock microstructures}

Contact metamorphic reactions, developed at various distances from the pluton margins, are reconstructed by microstructural analysis (fig. 11). Among the pre-intrusive phases, Omp is widely replaced even where the country rocks are weakly transformed. The most contact metamorphism-resistant minerals are Rt and Grt; locally Grt, Wm, Amp, and also Chl are still well preserved also close to the pluton margin. At equivalent distances from the pluton meta-aplites preserve better $\mathrm{Wm}, \mathrm{Grt}$, and Rt and show less developed Qtz polygonal structures than metapelites. The lack of internal plastic deformation features in contact metamorphic minerals suggests that contact metamorphism postdates the granular scale ductile deformations; alternatively this may be also due to a longer duration time of static re-crystallisation in HT conditions during the cooling, with respect to a potential granular scale ductile deformation.

\section{MICROSTRUCTURES OF IGNEOUS ROCK}

\section{Diorites and monzodiorites}


Two groups of diorites and monzodiorites are distinguished: medium-fine-grained and mediumcoarsegrained rocks.

Medium-fine-grained diorites consist of: Pl (60-70\%), Amp (10-20\%), Bt (8-10\%), Cpx (6-12\%), Qtz (5-10\%), opaque (1-2\%), and Ttn (0-2\%). Locally rocks contain up to $25 \%$ of $\mathrm{Kfs}$ and the composition is monzodioritic. Close to the margin with the country rock mediumfine-grained diorites are poorer in $\mathrm{Cpx}$ and $\mathrm{Hbl}$ and richer in Bt.

Medium-coarse-grained monzodiorites consist of: PI (50-70\%), Amp (5-25\%), Qtz (6-15\%), Bt (5-15\%), Kfs (10-25\%), Ttn (2-5\%), Cpx (2-3\%). Medium-fine-grained monzodiorites have the highest content in Qtz and Amp and form m-thick apophyses, which are poorer in Kfs and intrudes the country rock.

SPO of euhedral PI crystals marks a magmatic foliation in diorites and mozodiorites (fig. 12a). PI shows growth twinning and rims due to reaction with the residual melt. Crystals show growth zoning and the biggest crystals (PIII) contain smaller PI crystals (PII) (fig. 12b). Locally the outer part of PIII crystals is also interstitial. Bt forms large crystals, which enclose subhedral Pll crystals (fig. 12c). Cpx forms subhedral crystals often overgrown by Ampll. Ampll forms also interstitial crystals (fig. 12a) as well as Qtz, Kfs, and Ttn, while very rare Ampl is contained in PIII crystals. Perthitic Kfs is locally poikilitic and encloses PII, Bt, and Ampll. Generally crystals are weakly or not deformed. Close to the contact the magmatic foliation fits very well in the shape of the country rock (fig. 12d). Euhedral Kfs and Qtz, with rare interstitial PI, crystallised in fractures and along the S2 surfaces of the country rock (fig. 12e) and may represent the residual melt of the diorite. Very rare $\mathrm{Chl}$ and $\mathrm{Ep}$ overgrew respectively $\mathrm{Bt}$ and $\mathrm{PI}$ more often close to the contact with the country rock. The following order of crystallisation for the magmatic phases is therefore proposed: PII, Cpx, and Ampl appear to be the first phases; they were followed by PIII, Bt, and Ampll and by $\mathrm{Qtz}, \mathrm{Kfs}$, and Ttn. Ampll may derive also from reaction between residual melt and $\mathrm{Cpx}$. Ep and $\mathrm{Chl}$ developed from sub-solidus reaction.

Leucocratic dykes

Qtz-rich, Kfs-rich, and porphyritic leucocratic dykes intrude the pluton. In Qtz-rich dykes the grain size increases towards the core of the dyke; Qtz crystals are locally perpendicular to the country rock-wall. The outer part of the dykes is rich in $\mathrm{Kfs}$, widely overgrown by fine-grained $\mathrm{Wm}$. Locally these dykes are parallel to the magmatic foliation of the diorite. At the contact with these dykes $\mathrm{Pl}$ in the diorites is widely overgrown by Wm and Ep. Kfs-rich dykes consist of: Kfs (80\%), Cpx (10\%), partially overgrown by Amp (4\%), subhedral Ttn (5\%), and Qtz (1\%). Pl is very rare. Kfs encloses the other phases except Qtz. In the core of the dykes fine-grained Kfs crystals form a layer parallel to the margin of the dyke, which may have crystallised by residual melt. These dykes are sub-orthogonal to the magmatic foliation in the diorite. Porphyritic dykes consists of $\mathrm{Pl}, \mathrm{Amp}$, and rare Bt phenocrysts. The ground mass consists of anhedral $\mathrm{Kfs}, \mathrm{Pl}$, and Qtz. Bt phenocrysts partially enclose PI (fig. 12e) suggesting that Bt grew after or finished to grow after $\mathrm{PI}$. Phenocrysts mark a magmatic foliation, which is parallel to the margin of the dykes and to the magmatic foliation

Andesitic dykes

Andesitic dykes show a porphyritc texture with phenocrysts of $\mathrm{Pl}, \mathrm{Amp}$, and $\mathrm{Bt}$, which are widely altered. Locally they preserve rare and pristine Amp phenocrysts. Wm, Chl, and Ep overgrew PI. Amp and Bt are mainly replaced by $\mathrm{Chl}$. The ground mass, which mainly consists of well preserved $\mathrm{Pl}$, is overgrown by $\mathrm{Chl}$ and minor Wm. 
A summary of the chemical mineral compositions acquired both on plutonic and country rocks, affected by contact metamorphism, is here provided, in order to estimate the crustal condition of pluton emplacement. In metapelites the Ti content (0-0.5 a.p.f.u.) of Bt decreases with the distance from the pluton and indicates peak temperatures between 700 and $580^{\circ} \mathrm{C}$ (HENRY et alii, 2005). In metapelites and metagranitoids the $\mathrm{Fe}-\mathrm{Mg}$ exchange reaction between $\mathrm{Sp}(\mathrm{Fe} / \mathrm{Fe}+\mathrm{Mg}=0.84-0.91)$ and $\mathrm{Crd}(\mathrm{Fe} / \mathrm{Fe}+\mathrm{Mg}=$ 0.40-0.54) indicates temperatures of $725-700^{\circ} \mathrm{C}$ (VIELZEUF, 1983) up to $10 \mathrm{~m}$ far from the pluton (in plan view). The NaSi-CaAl exchange reaction between $\mathrm{Amp}(\mathrm{Ti}=0-0.05 ; \mathrm{Al}=0.62-0.83 ; \mathrm{Na}=0.45-0.59 ; \mathrm{Ca}=$ 1.62-1.19 a.p.f.u.) and $\mathrm{PI}(\mathrm{XAb}=0.81-0.83)$ in symplectites after Omp indicates temperatures between 590 and $530^{\circ} \mathrm{C}$ (HOLLAND \& BLUNDY, 1994) at distances between 35 and $350 \mathrm{~m}$ from the pluton (in plan view). The Al/Si ratio in Amp ( 0.1) and PI (0.45-0.5) indicates pressures lower than 0.2 GPa (FERSHTATER, 1990). In diorites interstitial Amp shows Ti (0.09-0.15 a.p.f.u.) and Al (0.95-1.20 a.p.f.u.) contents indicating temperatures of $650 \pm 25^{\circ} \mathrm{C}$ and pressures of 0.1-0.2 GPa respectively (OTTEN, 1984; HAMMARSTROM \& ZEN, 1986; HOLLISTER et alii, 1987; JOHNSON \& RUTHERFORD, 1989; SCHMIDT, 1992; ANDERSON \& SMITH, 1995). NaSi-CaAl exchange reaction between Amp ( $\mathrm{Na}=0.28-0.55 ; \mathrm{Ca}=1.77-1.92$ a.p.f.u.) and $\mathrm{PI}(\mathrm{XAb}=$ 0.44-0.72) (HOLLAND \& BLUNDY, 1994) yields temperatures of $725 \pm 70^{\circ} \mathrm{C}$ that are more reliable since the thermometer based on the content of Ti in Amp is calibrated for basaltic compositions (OTTEN, 1984). The pressure estimated by the Al/Si ratio in Amp ( 0.1) and in PI (0.5-0.6) (FERSHTATER, 1990) accords with that obtained by the Al content in Amp.

\section{DISCUSSIONS AND CONCLUSIONS}

The country rocks of the north-eastern margin of the Traversella pluton record five ductile deformation phases; the first two are coeval with the eclogite facies metamorphism and the second is responsible for the development of the regional foliation in the country rocks. The third ductile deformation stage is here interpreted as coeval with retrograde blueschist facies metamorphism. The last two ductile deformation stages are interpreted as accompanying the exhumation tectonic process, during the development of the greenschist facies metamorphism. The different orientation of the pervasive S2 foliation with respect to the magmatic foliation suggests that the ductile deformation stages affecting the country rocks are not recorded in the pluton and that the intrusion did not cause significant ductile deformation in the country rocks.

The attitude of the magmatic foliation is steeply dipping and sub-parallel to the contact with the country rocks, which has probably driven the magmatic flow during the emplacement; this is even clear at the microscale because the magmatic foliation marked by PI crystals is adapting to the shape of the contact surface with the country rocks. This agrees with the orientation of the magnetic fabrics in the pluton, suggesting that, during the emplacement, magmatic flow was regular as in the case of a large dyke (HROUDA \& LANZA, 1989).

Generally the brittle structures are recorded with a similar frequency in country and plutonic rocks indicating that most of the brittle deformation postdates the intrusion. The B2 structures, pervasively recorded in the area, are possibly related to the Canavese line activity, which lasts after the intrusion. Probably B1 brittle structures mainly predate the intrusion of the pluton, since they are recorded mainly in the basement. The Qtz-bearing fractures, which intersect the regional foliation and are radial with respect to the pluton margin, may well have formed by magma pushing during the pluton emplacement; the SesiaLanzo Zone basement was therefore at a crustal level compatible with dominant brittle behaviour, also in accordance to contact metamorphism overprinting the greenschist facies regional metamorphism. 
Mineralised fractures in the plutonic rocks, which show a radial orientation with respect to the pluton margin or a parallel orientation with respect to the magmatic foliation, may have formed by magma cooling during the final stages of emplacement. Leucocratic dykes intruding plutonic rocks show radial orientation with respect to the pluton margin or are parallel to the magmatic foliation; the sharp edges of these dykes and a magmatic foliation generally parallel to the margins suggest that they intruded the pluton when it was at least almost completely crystallised. In particular some of these dykes display a porphyritic structure, which may be compatible with a shallow crystallisation level. Fracture filling and magma forming dykes may represent respectively residual fluids and melt coming from the pluton, which may have circulated in brittle systems during final cooling stages. The dyke magma may have fractionated from the dioritic magma (VAN MERKE DE LUMMEN \& VANDER AUWERA, 1990).

The representation on the geological map (plate I) of the different modal amount of contact metamorphic minerals in each lithotypes allows to envisage the following parameters that may control the local extent of the contact aureole: a) the country rock permeability related to the quantity of oriented $\mathrm{Wm}$, because at equivalent distances from the pluton margin in meta-aplites $\mathrm{Wm}$ is better preserved than in metapelites; $b$ ) content in phases sensitive to contact metamorphism like Omp; c) reciprocal orientation between pervasive foliation in country rock and pluton margin: for instance close to the M. Gregorio ridge, where the foliation is sub-parallel to the pluton margin, the contact aureole is narrower.

The structural relationships among pluton and country rocks suggest shallow crustal level of emplacement, since: a) the pluton intersect the syn-greenschist struc tures in the country rocks; b) the contact metamorphic minerals replace minerals characteristic of greenschist facies conditions; $c$ ) the deformations postdating the pluton intrusion are mainly brittle. These evidences agree with the occurrence of $\mathrm{Crd}$ and Sp bearing assemblage in metapelites and in metagranitoids, and of And and Crn (WIRTH, 1985; VANDER AUWERA, 1990) allowing to estimate $T \leq 750^{\circ} \mathrm{C}$ and $\mathrm{P} \leq 0.2 \mathrm{GPa}$ as peak conditions of contact metamorphism. Similar PT conditions are envisaged for other contact metamorphic mineral assemblages (WIRTH, 1985, 1986) and for the crystallisation conditions of the pluton (VAN MERKE DE LUMMEN \& VANDER AUWERA, 1990). These conditions are compatible with the development of partial melting in metapelites suggested by diagnostic microstructures and geochemical investigations (VAN MERKE DE LUMMEN \& VANDER AUWERA, 1990). Similar crustal emplacement conditions have been inferred for the coeval Biella pluton (ZANONI, 2007; ZANONI et alii, 2008).

As for other periadriatic igneous bodies, the intrusion of the $30 \mathrm{Ma}$ old Traversella pluton may have been triggered by the slab break off (VON BLANCKENBURG \& DAVIES, 1995), which, according to numerical modelling, may have taken place $10 \mathrm{Ma}$ after the end of the oceanic subduction (e.g. GERYA et alii, 2004; MAROTTA \& SPALLA, 2007; SPALLA \& MAROTTA, 2007). Since the Sesia-Lanzo Zone has been mainly exhumed in depressed geothermic conditions, compatible with a still active oceanic subduction (MEDA et alii, in press), and the youngest age of oceanic crust eclogitisation in the Western Alps is around $40 \mathrm{Ma}$, the Sesia-Lanzo Zone would have had enough time to reach a shallow crustal level before the intrusion of the Oligocene magmas. In addition metamorphic pebbles, consisting of EMC rocks, in the Oligocene basal conglomerate, discordant upon the Sesia-Lanzo Zone basement (BIANCHI \& DAL PIAZ, 1963), suggest that Sesia-Lanzo Zone was already exposed to erosion at the moment of the intrusion of the Oligocene plutons, because the volcanic andesites, stratigraphically younger than this basal conglomerate, display ages between 29 and $33 \mathrm{Ma}$ (SCHEURING et alii, 1973).

\section{ACKNOWLEDGEMENTS}


Two anonymous reviewers helped to improve the clearness of the manuscript and the map presentation. G. Gosso and M.I. Spalla tutored the author's Ph.D. thesis. C.L. Rosenberg and M. Zucali are acknowledged for fruitful discussions. C. Malinverno provided thin sections and A. Rizzi the technical assistance at the Scanning Electron Microscope at the "A. Desio» Earth Science Department of the Milano University. The Brosso mayor, Mr. Presbitero-Bracco, supplied facilities during fieldwork. Funding by FIRST of G. Gosso.

\section{REFERENCES}

AMATO J.M., JOHNSON C.M., BAUMGARTNER L.P. \& BEARD B.L. (1999) - Rapid exhumation of the ZermattSaas ophiolite deduced from high-precision Sm-Nd and Rb-Sr geochronology. EarthPlanet. Sci. Lett., 171, 425-438.

ANDERSON J.L. \& SMITH D.R. (1995) - The effects of temperature and fo2 on the Al-in-hornblende barometer. Am. Miner., 80, 549-559.

ANDREOLI M., COMPAGNONI R. \& LOMBARDO B. (1976) - Jadeite megablasts from Valchiusella (SesiaLanzo zone, Western Alps). Rend. Soc. It. Min. Petrol., 32, 681-698.

BECCALUVA L., BIGIOGGERO B., CHIESA S., COLOMBO A., FANTI G., GATTO G.O., GREGNANIN A., MONTRASIO A. \& TUNESI A. (1983) - Post-collisional orogenic dyke magmatism in the Alps. Mem. Soc. Geol. It., 26, 341-359.

BERGBAUER S. \& MARTEL S.J. (1999) - Formation of joints in cooling plutons. J. Struct. Geol., 21, 821-835.

BIANCHI A. \& DAL PIAZ G. (1963) - Gli inclusi di «micascisti eclogitici» della zona Sesia nella formazione porfiritica permiana della zona del Canavese fra Biella ed Oropa. Caratteristiche ed età dei fenomeni metamorfici. Giorn. Geol., 31, 39-76.

BIGIOGgeRO B., COLOMBO A., DEL MORO A., GREGNANIN A., MACERA P. \& TUNESI A. (1994) - The Oligocene Valle del Cervo Pluton: an example of shoshonitic magmatism in the Western Italian Alps. Mem. Sci. Geol., Padova, 46, 409-421.

BUSSY F., VENTURINI G., HUNZIKER J. \& MARTINOTTI G. (1998) - U-Pb ages of magmatic rocks of the western Austroalpine Dent-Blanche-Sesia Unit. Schweiz. Miner. Petrog. Mitt., 78, 163-168.

CALLEGARI E., CIGOLINI C., MEDEOT O. \& D'ANTONIO M. (2004) - Petrogenesis of calcalkaline and shoshonitic post-collisional Oligocene volcanics of the Cover Series of the Sesia Zone, Western Italian Alps. Geodinamica Acta, 17, 1-29.

CASTELLI D. (1991) - Eclogitic metamorphism in carbonate rocks: the example of impure marbles from the Sesia-Lanzo Zone, Italian Western Alps. J. Metamorph. Geol., 9, 61-77.

CLIFF R.A., BARNICOAT A.C. \& INGER S. (1998) - Early Tertiary eclogite facies metamorphism in the Monviso Ophiolite. J. Metamorph. Geol., 16, 447-455.

COMPAGNONI R., DAL PIAZ G.V., HUNZIKER J.C., GOSSO G., LOMBARDO B. \& WILLIAMS P.F. (1977) - The Sesia-Lanzo Zone: a slice of continental crust, with alpine HP-LT assemblages in the Western Italian Alps. Rend. Soc. It. Min. Petrol., 33, 281-334. 
CORTIANA G., DAL PIAZ G.V., DEL MORO A., HUNZIKER J.C. \& MARTIN S. (1998) - 40Ar-39Ar and Rb-Sr dating of the Pillonet klippe and Sesia-Lanzo basal slice in the Ayas valley and evolution of the AustroalpinePiedmont nappe stack. Mem. Sci. Geol., 50, 177-194.

DAL PIAZ G.V., CORTIANA G., DEL MORO A., MARTIN S., PENNACCHIONI G. \& TARTAROTTI P. (2001) Tertiary age and paleostructural inferences of the eclogitic imprint in the Austroalpine outliers and ZermattSaas ophiolite, western Alps. Int. J. Earth Sci., 90, 668-684.

DE CAPITANI L., FIORENTINI POTENZA M., MARCHI A. \& SELLA M. (1979) - Chemical and Tectonic contributions to the age and petrology of the Canavese and Sesia-Lanzo «porphyrites». Atti Soc. It. Sci. Nat., 120, 151-179.

DESMONS J., COMPAGNONI R., FREY M. \& GAGGERO L. (1999) - Pre-Alpine metamorphism in the Internal zones of the Western Alps. Schweiz. Miner. Petrog. Mitt., 79, 23-40.

DUBRU M., VANDER AUWERA J., VAN MERKE DE LUMMEN G. \& VERKAEREN J. (1988) - Distribution of scheelite in magnesian skarns at Traversella (Piemontese Alps, Italy) and Costabonne (Eastern Pyrenees France). Nature of associated magmatism and influence of fluid composition. In: Boissonas J. \& Omenetto P. (Eds.), Mineral Deposits within the European Community. Special Publication of the Society for Geology Applied to Mineral Deposits, 6, 177-134.

DUCHENE S., BLICHERT-TOFT J., LUAIS B., TÉLOUK P., LARDEAUX J.M. \& ALBAREDE F. (1997) - The Lu-Hf dating of garnets and the ages of the Alpine high-pressure metamorphism. Nature, 387, 586-589.

FERSHTATER G.B. (1990) - Empirical hornblende-plagioclase geobarometer. Geokhimiya, 3, 328-335.

GERYA T.V., YUENC D.A. \& MARESCHD W.V. (2004) - Thermomechanical modelling of slab detachment. Earth Planet. Sci. Lett., 226, 101-116.

GOSSO G. (1977) - Metamorphic evolution and fold history in the eclogite micaschists of the upper Gressoney valley (Sesia-Lanzo zone, Western Alps). Rend. Soc. It. Min. Petrol., 33, 389-407.

HAMMARSTROM J. \& ZEN E.-A. (1986) - Aluminum in hornblende; an empirical geobarometer. Am. Miner., 71, 1297-1313.

HANDY M.R., BABIST J., WAGNER R., ROSENBERG C.L. \& KONRAD M. (2005) - Decoupling and its relations to strain partitioning in continental lithosphere: insight from the Periadriatic fault system (European Alps). In: Gapais D., Brun J.P. \& Cobbold P.R. (Eds.), Deformation Mechanism, Rheology and Tectonics: from Minerals to Lithosphere. Geol. Soc. Lond. Spec. Publ., 243, 249-276.

HENRY D., GUIDOTTI C. \& THOMSON J. (2005) - The Ti-saturation surface for low-to-medium pressure metapelitic biotites: Implications for geothermometry and Ti-substitution mechanisms. Am. Miner., 90, 316-328.

HOLLAND T.J.B. \& BLUNDY J. (1994) - Non-ideal interactions in calcic amphiboles and their bearing on amphibole-plagioclase thermometry. Contrib. Miner. Petrol., 116, 433-447.

HOLLISTER L.S., GRISSOM G.C., PETERS E.K., STOWELL H.H. \& SISSON V.B. (1987) - Confirmation of the empirical correlation of $\mathrm{Al}$ in hornblende with pressure of solidification of calc-alkaline plutons. Am. Miner., 72, 231-239. 
HROUDA F. \& LANZA R. (1989) - Magnetic fabric in the Biella and Traversella stocks (Periadriatic Line); implications for the mode of emplacement. Physics Earth Planet. Int., 56, 337-348.

ILDEFONSE B., LARDEAUX J.M. \& CARON J.M. (1990) - The behaviour of shape preferred orientations in the metamorphic rocks: amphiboles and jadeites from the Monte Mucrone Area (Sesia-Lanzo Zone, Italian Western Alps). J. Struct. Geol., 12, 1005-1011.

INGER S. \& RAMSBOTHAM W. (1997) - Syn-convergent exhumation implied by progressive deformation and metamorphism in the Valle dell'Orco transect, NW Italy Alps. J. Geol. Soc., Lond., 154, 667-677.

INGER S., RAMSBOTHAM W., CLIFF R.A. \& REX D.C. (1996) - Metamorphic evolution of the Sesia-Lanzo Zone, Western Alps: time constraints from multi-system geochronology. Contrib. Miner. Petrol., 126, 152168.

JOHNSON M.C. \& RUTHERFORD M.J. (1989) - Experimental calibration of the aluminum-in-hornblende geobarometer with application to Long Valley Caldera (California) volcanic rocks. Geology. 17, 837-841.

JUNG S., HOERNES S. \& MEZGER K. (2000) - Geochronology and petrology of migmatites from the Proterozoic Damara Belt-importance of episodic fluid-present disequilibrium melting and consequences for granite petrology. Lithos, 51, 153-179.

KANO S. \& TSUCHIYA N. (2002) - Parallelepiped cooling joint and anisotropy of P-wave velocity in the Takidani granitoid, Japan Alps. J. Volcanol. Geotherm. Res., 114, 465-477.

KOENDERS M.A. \& PETFORD N. (2003) - Thermally induced primary fracture development in tabular granitic plutons: a preliminary analysis. In: Petford N. \& McCaffrey K.J.W. (Eds.), Hydrocarbon in Crystalline Rocks. Geol. Soc. Lond. Spec. Publ., 214, 143-150.

KRUMMENACHER D. \& EVERNDEN J. (1960) - Détermination d'âge isotopique sur quelques roches des Alpes par la méthode K-Ar. Schweiz. Miner. Petrog. Mitt., 40, 267-277.

LANZA R. (1984) - Palaeomagnetism in the Traversella massif. Boll. Geof. Teor. Appl., 26, 115-124.

LARDEAUX J.M., GOSSO G., KIENAST J.R. \& LOMBARDO B. (1982) - Relations entre le métamorphisme et la déformation dans la zone Sésia-Lanzo (Alpes Occidentales) et le problème de l'éclogitisation de la croûte continentale. Bull. Soc. géol. Fr., 24, 793-800.

LARDEAUX J.M. \& SPALLA M.I. (1991) - From granulites to eclogites in the Sesia zone (Italian Western Alps): a record of the opening and closure of the Piedmont ocean. J. Metamorph. Geol., 9, 35-59.

MAROTTA A.M. \& SPALLA M.I. (2007) - Permian-Triassic high thermal regime in the Alps: Result of late Variscan collapse or continental rifting? Validation by numerical modeling. Tectonics, 26, 10.1029/2006TC002047.

MEDA M., MAROTTA A.M. \& SPALLA M.I. (in press) - The role of mantle hydration into the continental crust recycling in the wedge region. Geol. Soc. London Spec. Publ.

OBERHÄNSLI R., HUNZIKER J.C., MARTINOTTI G. \& STERN W.B. (1985) - Geochemistry, geochronology and petrology of Monte Mucrone: an example of Eo-Alpine eclogitization of Permian granitoids in the SesiaLanzo Zone, Western Alps, Italy. Chem. Geol., 52, 165-184. 
OTTEN M.T. (1984) - The origin of brown hornblende in the Artfjaellet gabbro and dolerites. Contrib. Miner. Petrol., 86, 189-199.

PASSCHIER C.W. \& TROUW R.A.J. (2005) - Microtectonics, Springer, Berlin Heidelberg New York.

PASSCHIER C.W., URAI J.L., VAN LOON J. \& WILLIMAS P.F. (1981) - Structural geology of the Central SesiaLanzo Zone. Geologie en Mijnbouw, 60, 497-507.

PATERSON S.R., VERNON R.H. \& TOBISCH O.T. (1989) - A review of criteria for the identification of magmatic and tectonic foliation in granitoids. J. Struct. Geol., 11, 349-363.

POGNANTE U. (1989) - Lawsonite, blueschist and eclogite formation in the southern Sesia Zone (Western Alps, Italy). Eur. J. Miner., 1, 89-104.

POGNANTE U. (1991) - Petrological constraints on the eclogite- and blueschist-facies metamorphism and PT-t paths in the Western Alps. J. Metamorph. Geol., 9, 5-17.

POGNANTE U., COMPAGNONI R. \& GOSSO G. (1980) - Micromesostructural relationships in the continental eclogitic rocks of the Sesia-Lanzo zone: a record of a subduction cycle (Italian Western Alps). Rend. Soc. It. Min. Petrol., 36, 169-186.

POGNANTE U., TALARICO F. \& BENNA P. (1987) - Incomplete blueschist re-crystallization in high grade metamorphics from the Sesia-Lanzo unit (Vasario-Sparone subunit, Western Alps ophiolites): a case history of metastability. Lithos, 21, 129-142.

POLINO R., DAL PIAZ G.V. \& GOSSO G. (1990) - Tectonic erosion at the Adria margin and accretionary processes for the Cretaceous orogeny of the Alps. Mem. Soc. géol. Fr., 156, 345-367.

REBAY G. \& SPALLA M.I. (2001) - Emplacement at granulite facies conditions of the Sesia-Lanzo metagabbros: an early record of Permian rifting? Lithos, 58, 85-104.

RIDLEY J. (1989) - Structural and metamorphic history of a segment of the Sesia-Lanzo Zone, and its bearing on the kinematics of Alpine deformation in the Western Alps. In: Coward M.P., Dietrich D. \& Park R.G. (Eds.), Conference on Alpine tectonics., London, United Kingdom. Geol. Soc. Lond., 45, 189-201.

ROMAIN-BERDIEL T. \& PUEYO-MORER E.L. (2000) - Distribution d'orientation des joints et relation avec I'anisotropie magmatique primaire dans le massif granitique de Trives (Nord-Ouest de l'Espagne). C.R. Acad. Sci. Paris, Sciences de la Terre et des planètes, 330, 437-443.

ROMER R., SCHÄRER U. \& STECK A. (1996) - Alpine and pre-Alpine magmatism in the root-zone of the Western Central Alps. Contrib. Miner. Petrol., 123, 138-158.

ROSENBERG C.L. (2004) - Shear zones and magma ascent: a model based on a review of the Tertiary magmatism in the Alps. Tectonics, 23, 1-21.

ROSENBERG C.L. \& RILLER U. (2000) - Partial-melt topology in statically and dynamically recrystallized granite. Geology, 28, 7-10.

RUBATTO D., GEBAUER D. \& COMPAGNONI R. (1999) - Dating of eclogite-facies zircons; the age of Alpine metamorphism in the Sesia-Lanzo Zone (Western Alps). Earth Planet. Sci. Lett., 167, 141-158. 
RUFFET G., GRUAU G., BALLÉVRE M., FERAUD G. \& PHILIPPOT P. (1997) - Rb-Sr and (super 40) Ar- (super 39) Ar laser probe dating of high-pressure phengites from the Sesia Zone (Western Alps); underscoring of excess argon and new age constraints on the highpressure metamorphism. Chem. Geol., 141, 1-18.

SCHEURING B., AHRENDT H., HUNZIKER J.C. \& ZINGG A. (1973) - Paleobotanical and geochronological evidence for the Alpine age of the metamorphism in the Sesia-Zone. Geolog. Rund., 63, 305-326.

SEGALL P. \& POLLARD D.D. (1983) - Joint formation in granitic rock of the Sierra Nevada. Geol. Soc. Am. Bull., 94, 563-575.

SCHMIDT M.W. (1992) - Amphibole composition in tonalite as a function of pressure: An experimental calibration of the Al-in-hornblende barometer. Contrib. Miner. Petrol., 110, 304-310.

SPALLA M.I., DE MARIA L., GOSSO G., MILETTO M. \& POGNANTE U. (1983) - Deformazione e metamorfismo della Zona Sesia-Lanzo meridionale al contatto con la falda piemontese e con il massiccio di Lanzo, Alpi occidentali. Mem. Soc. Geol. It., 26, 499-514.

SPALLA M.I., LARDEAUX J.M., DAL PIAZ G.V. \& GOSSO G. (1991) - Métamorphisme et tectonique à la marge externe de la zone Sesia-Lanzo (Alpes Occidentales). Mem. Sci. Geol., 43, 361-369.

SPALLA M.I., LARDEAUX J.M., DAL PIAZ G.V., GOSSO G. \& MESSIGA B. (1996) - Tectonic significance of Alpine eclogites. J. Geodyn., 21, 257-285.

SPALLA M.I. \& MAROTTA A.M. (2007) - P-T evolutions vs. numerical modeling: a key to unravel the Paleozoic to Early-Mesozoic tectonic evolution of the Alpine area. Per. Miner., 76, 267-308.

STEVENS G., CLEMENS J.D. \& DROOP G.T.R. (1997) - Melt production during granulite-facies anatexis: experimental data from «primitive» metasedimentary protoliths. Contrib. Mineral. Petrol., 128, 352-370.

STÜNITZ H. (1989) - Partitioning of metamorphism and deformation in the boundary region of the «Seconda Zona Dioritico-Kinzigitica », Sesia Zone, Western Alps. PhD Thesis n 8817, ETH, Zürich.

VAN MERKE DE LUMMEN G. \& VANDER AUWERA J. (1990) - Petrogenesis of Traversella diorite (Piemonte Italy): a major trace element and isotopic (O, Sr) model. Lithos, 24, 121-136.

VANDER AUWERA J. (1990) - The porphyritic facies and the endoskarns of the Traversella monzodiorite: Implications for the evolution of the main intrusion (Ivrea, Italy). Schweiz. Miner. Petrog. Mitt., 70, 237-245.

VENTURINI G., MARTINOTTI G. \& HUNZIKER J.C. (1991) - The protoliths of the Eclogitic Micaschists in the lower Aosta Valley (Sesia-Lanzo zone, Western Alps). Mem. Soc. Geol. It., 43, 347-359.

VERNON R.H. (2004) - A practical guide to rock microstructure, Cambridge University Press.

VIELZEUF D. (1983) - The spinel and quartz association in high grade xenoliths from Tallante (SE Spain) and their potential use in geothermobarometry and barometry. Contrib. Miner. Petrol., 82, 301-311.

VON BLANCKENBURG F. \& DAVIES J.H. (1995) - Slab breakoff. A model for syncollisional magmatism and tectonics in the Alps. Tectonics, 14, 120-131.

VON BLANCKENBURG F., KAGAMI H., DEUTSCH A., OBERLI F., MEIER M., WIEDENBECK M., BARTH S. \& FISCHER H. (1998) - The origin of Alpine plutons along the Periadriatic Lineament. Schweiz. Miner. Petrog. Mitt., 78, 55-65. 
WILLIAMS P.F. \& COMPAGNONI R. (1983) - Deformation and metamorphism in the Bard area of the SesiaLanzo zone, Western Alps, during subduction and uplift. J. Metamorph. Geol., 1, 117-140.

WIRTH R. (1985) - Dehydration and thermal alteration of white mica (phengite) in the contact aureole of the Traversella Intrusion. N. Jahr. Min. Abh., 152, 101-112.

WIRTH R. (1986) - Thermal alteration of glaucophane in the contact aureole of the Traversella Intrusion (NItaly). N. Jahr. Min. Abh., 154, 193-205.

ZANONI D. (2007) - Messa in posto di plutoni tardo collisionali in unità continentali profonde esumate. L'esempio della Zona Sesia Lanzo (Alpi Occidentali Interne). Ph.D. Thesis, Università di Milano.

ZANONI D., BADO L., SPALLA M.I., ZUCALI M. \& GOSSO G. (2008) - Structural analysis of the Northeastern margin of the Tertiary intrusive stock of Biella (Western Alps, Italy). Boll. Soc. Geol. It. (Ital. J. Geosci.), 127, 125-140.

ZUCALI M., SPALLA M.I. \& GOSSO G. (2002) - Strain partitioning and fabric evolution as a correlation tool: the example of the eclogitic micaschists complex in the Sesia-Lanzo Zone (Monte Mucrone- Monte Mars, Western Alps Italy). Schweiz. Miner. Petrog. Mitt., 82, 429-454.

Manuscript received 2 January 2009; accepted 30 September 2009; handled by E. Tavarnelli

Ital.J.Geosci. (Boll.Soc.Geol.It.), Vol. 129, No. 1 (2010)

Fig. 1 - a) Simplified tectonic outline of the Alps; b) Simplified geological map of the Sesia-Lanzo Zone; c) Geological sketch of the Traversella pluton, redrawn after VAN MERKE DE LUMMEN \& VANDER AUWERA (1990) showing the location of plate I (dashed line). - a) Schema tettonico semplificato delle Alpi; b) Schema geologico semplificato della Zona Sesia-Lanzo; c) Schema geologico del plutone di Traversella, ridisegnato da VAN MERKE DE LUMMEN \& VANDER AUWERA (1990) con la localizzazione della tav. I (linea tratteggiata).

Fig. 2 - a) Leucocratic dyke intruding the diorite; b) Andesitic dyke intersecting at a low angle the S2 regional foliation of the Traversella pluton country rock. - a) Dicco leucocrato intruso nella diorite; b) Dicco andesitico che interseca a basso angolo la foliazione regionale S2 della roccia incassante del plutone di Traversella.

Fig. 3 - a) S1 foliation that marks the boundary between meta-aplites and metapelites and folded during the development of S2 schistosity (D2); close to M. Gregorio summit; b) Syn-D2 s-c structures in the metaaplites; close to Le Colme; c) S2 folded during D4; close to Gr. Piani; d) S2 gently bent during D5; close to Gr. Piani; e) Irregular contact between diorite and meta-aplites crosscut by a B2 fracture; close to Gr. Doglia; f) Diorite crosscutting a D4 fold limb; north of Caras. - a) S1 che marca il limite tra meta-apliti e metapeliti, piegata durante la deformazione scistogena D2; b) Strutture s-c sin-D2 nelle metaapliti vicino a Le Colme; c) S2 piegata durante lo stadio D4; vicino a Gr. Piani; d) S2 ondulata dal piegamento D5; vicino a Gr. Piani; e) Contatto irregolare tra diorite e meta-apliti, intersecato da una frattura B2; vicino a Gr. Doglia; f) Diorite che interseca il fianco di una piega D4; a nord di Caras.

Fig. 4 - Equal area Schimdt synoptic projections (lower hemisphere) of the orientation of planar and linear fabric during ductile deformation of the country rocks; «n» = number of data. - Proiezioni sinottiche 
equiareali di Schimdt (emisfero inferiore) dell'orientazione degli elementi strutturali planari e lineari delle deformazioni duttili registrate nelle rocce incassanti; «n» = numero di dati. into a new tectonostratigraphic sequence, as for instance shown in cross sections $A-A^{\prime}$ and $B-B^{\prime}$. Along cross section $C-C^{\prime}$ the huge implication of igneous within country rocks, evident at $A^{-} A^{\prime}$ and $B-B^{\prime}$ intersections, is interpreted as a later nearly horizontal pluton apophysis, of intrusive shape, poorly modified in its configuration after intrusion.

Fig. 5 - Equal area Schimdt projections (lower hemisphere) of the orientation of ductile structural elements recorded in the country rocks, subdivided in subareas. - Proiezioni equiareali di Schimdt (emisfero inferiore) degli elementi strutturali delle deformazioni duttili registrate nelle rocce incassanti, suddivise in subaree.

Fig. 6 - a) Dextral shear zone reworked by brittle shear (B1), in fine-grained metagranitoids at Gr. Piani locality; b) Cataclastic bands reworking S2 regional foliation in metapelites; close to Capannette; c) B2 pervasive fractures on the western slope of M. Gregorio ridge; d) Possible cooling fractures in the diorite close to Gr. Doglia; e) Cooling fracture crosscutting exclusively the diorite; north of Caras; f) Qtz-rich fractures cutting across the regional foliation; close to Gr. Doglia. - a) Zona di taglio destro ripresa da zona di taglio fragile B1, vicino a Gr. Piani; b) Zone cataclastiche che riattivano la foliazione regionale S2 nelle metapeliti; vicino a Capannette; c) Fratture pervasive B2 lungo la parte occidentale della cresta del M. Gregorio; d) Probabili fratture da raffreddamento nella diorite nei pressi di Gr. Doglia; e) Fratture da raffreddamento esclusivamente localizzate nella diorite; a monte di Caras; f) Frattura mineralizzata a Qtz che interseca la foliazione regionale; vicino a Gr. Doglia.

Fig. 7 - Equal area Schimdt projections (lower hemisphere) of the brittle structural elements in the country and plutonic rocks. Orientation of B1, B2, B3, and B4 fractures is shown and is related to the localities where their relative chronology was inferred. Pole density diagrams for fractures in plutonic and country rocks are also shown; «n» = number of data. - Proiezioni equiareali di Schimdt (emisfero inferiore) degli elementi strutturali delle deformazioni fragili nelle rocce incassanti e plutoniche. L'orientazione delle fratture B1, B2, B3 e B4 è riferita alle località ove è stata ricavata la cronologia relativa tra le fratture. Sono mostrati anche i diagrammi di densità dei poli delle strutture fragili nelle rocce incassanti e plutoniche; «n» $=$ numero di dati. developed. At the contact with the pluton margin also Sil occurs among reaction products of Wm (fig. 10b).

Fig. 8 - Orientations of the mineralised fractures and of the leucocratic dykes in the country and plutonic rocks, indicated on the map and on the equal area Schimdt projections (lower hemisphere). - Orientazione delle fratture mineralizzate e dei dicchi leucocrati nelle rocce incassanti e plutoniche, in carta e in proiezione equiareale di Schimd (emisfero inferiore).

Fig. 9 - Microstructure in metapelites: a) Bt-PI-bearing corona between WmIl and Grt; backscattered SEM image; b) PI, Bt and Kfsll probably replacing a Gln crystal; backscattered SEM image; c) A few $\mathrm{cm}$ far from the pluton $\mathrm{Wml}$ and $\mathrm{Wm}$ ll still preserve the original shape, even if they are completely replaced by $\mathrm{Pl}, \mathrm{Bt}$, and Sp; plane polarised light; d) Interstitial Kfs between rounded Qtz crystals, few $\mathrm{cm}$ from the pluton margin; plane polarised light; e) Crd showing euhedral face against Qtz crystals occurs a few $\mathrm{cm}$ from the pluton; crossed polars; f) WmIl partially replaced by Bt and up to half mm-sized Crn, which are later replaced by WmV; backscattered SEM image. - Microstrutture nelle metapeliti: a) Corone a Bt e PI tra WmII e Grt; immagine in elettroni retrodiffusi; b) Pl, Bt e Kfsll che sostituiscono un probabile cristallo di Gln; immagine in elettroni retrodiffusi; c) A pochi $\mathrm{cm}$ dal plutone $\mathrm{Wml}$ e Wmll conservano ancora la forma originaria, anche se sono completamente sostituite da Pl, Bt e Sp; solo polarizzatore; d) Kfs interstiziale tra cristalli tondeggianti di Qtz a pochi cm dal plutone; solo polarizzatore; e) Crd mostra contatti netti con 
cristalli di Qtz a pochi cm dal contatto con il plutone; polarizzatore e analizzatore; f) Wmll parzialmente sostituita da $\mathrm{Crn}$ e Bt, che a loro volta sono sostituiti da WmV; immagine in elettroni retrodiffusi.

Fig. 10 - Microstructure in meta-aplites and metagranitoids: a) $\mathrm{Kfs}, \mathrm{Bt}$, and $\mathrm{Sp}$ replacing $\mathrm{Wm}$ in meta-aplites; backscattered SEM image; b) Sil developed as Wm reaction products in meta-aplites at the contact with the pluton margin; backscattered SEM image; c) Relict Chll preserved between Bt crystals in metagranitoids; backscattered SEM image; d) Ampl partially replaced by Ampll, Kfsll, and Bt in metagranitoids; backscattered SEM image. - Microstrutture in meta-apliti e metagranitoidi: a) Kfs, Bt e Sp che sostituiscono $\mathrm{Wm}$ in meta-apliti; immagine in elettroni retrodiffusi; b) Sil si forma tra i prodotti di reazione della Wm nelle meta-apliti al contatto con il plutone; immagine in elettroni retrodiffusi; c) Chll relitta preservata tra cristalli di Bt in metagranitoidi; immagine in elettroni retrodiffusi; d) Ampl parzialmente sostituito da Ampll, $\mathrm{Kfsll}$ e Bt in metagranitoidi; immagine in elettroni retrodiffusi.

Fig. 11 - Distance from the pluton margin in map view (logarithmic scale) of development of contact metamorphism reactions reconstructed by microstructural analysis. * indicates the reactions in metaaplites and metagranitoids; mineral phases completely replaced in each reaction are indicated in bold. Distanza in pianta (scala logaritmica) dal margine del plutone alla quale ricorrono le reazioni termometamorfiche ricostruite con l'analisi microstrutturale. ${ }^{*}$ indica le reazioni in meta-apliti e metagranitoidi; in neretto sono indicate le fasi completamente sostituite. in the diorite (fig. 12f). These dykes may be interpreted as sub-volcanic and, since they are parallel to the magmatic foliation in the diorite, they may have intruded cooling fractures.

Fig. 12 - Microstructures in magmatic rocks: a) SPO of PI marks the magmatic foliation in diorite; Ampll and Qtz are interstitial; crossed polars; b) PII enclosed in PIII in diorite; crossed polars; c) In diorites Bt encloses PII with irregular rims suggesting the occurrence of a reaction with the residual melt before the Bt growth; crossed polars; d) Magmatic foliation marked by SPO of PI fitting into the shape of the country rock margin; crossed polars; e) Bt individual partially enclosing a PI phenocryst in a porphyritic dyke suggesting that Bt growth probably terminated after growth of Pl; crossed polars; f) Magmatic foliation in porphyritic dyke positioned parallel to dyke margin and to the magmatic foliation in the flanking diorite; crossed polars. Microstrutture in rocce magmatiche: a) SPO di PI marca la foliazione magmatica nella diorite; Ampll e Qtz sono interstiziali; polarizzatore e analizzatore; b) PII incluso in PIII in diorite; polarizzatore e analizzatore; c) Nella diorite Bt include Pll con bordi irregolari, che suggeriscono una reazione con il liquido residuale prima dell'inclusione; polarizzatore e analizzatore; d) Foliazione magmatica marcata da PI che si adatta alla forma del contatto con la roccia incassante; polarizzatore e analizzatore; e) Fenocristallo di Bt in filone porfirico che ingloba parzialmente un fenocristallo di Pl; questo suggerisce che la Bt finisce di crescere dopo il Pl; polarizzatore e analizzatore; f) foliazione magmatica in dicco porfirico parallela al suo margine e alla foliazione magmatica nella diorite; polarizzatore e analizzatore. 


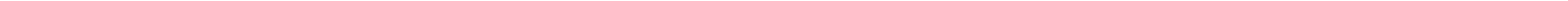



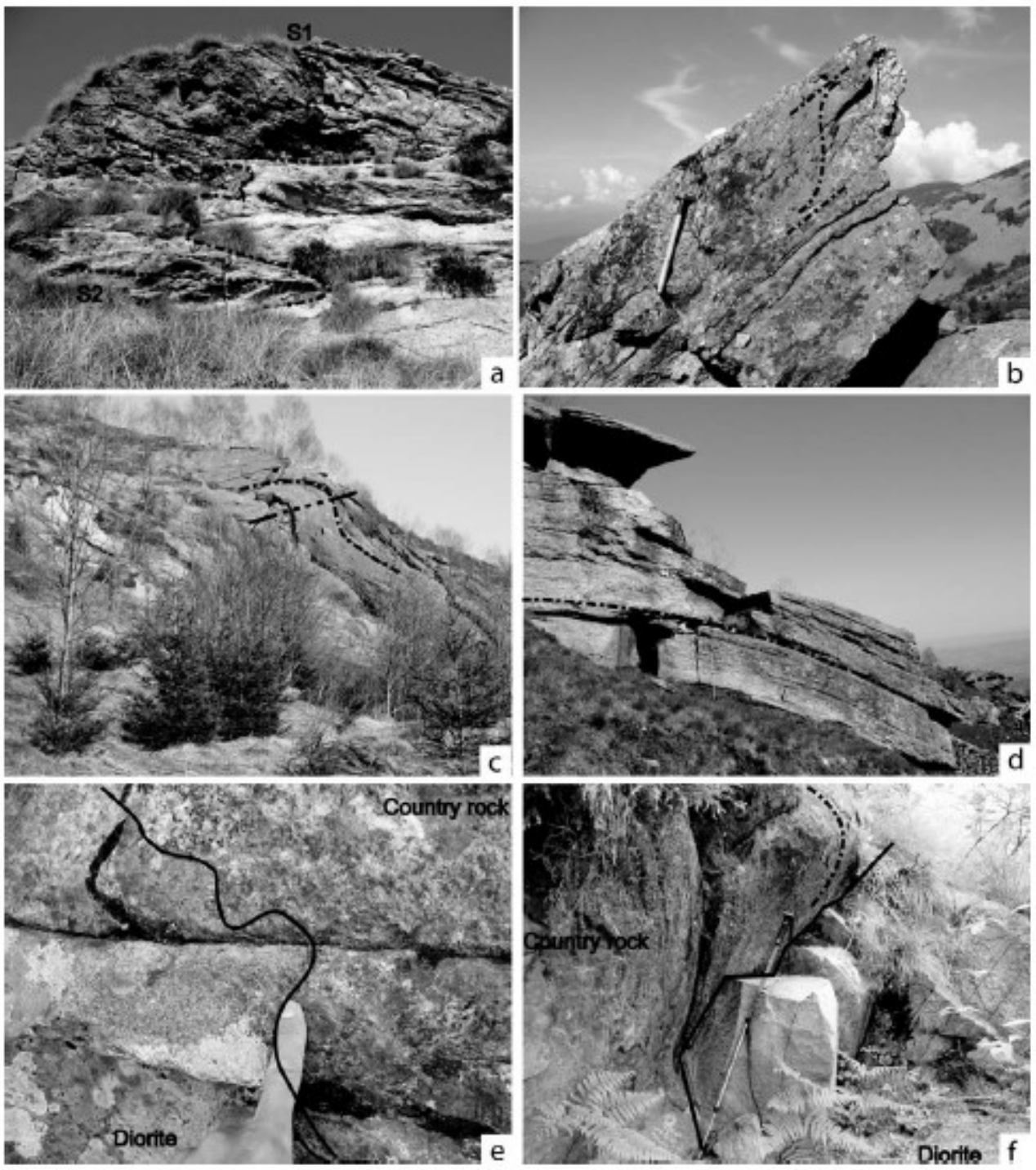


\section{D1}

D3

D4

D5

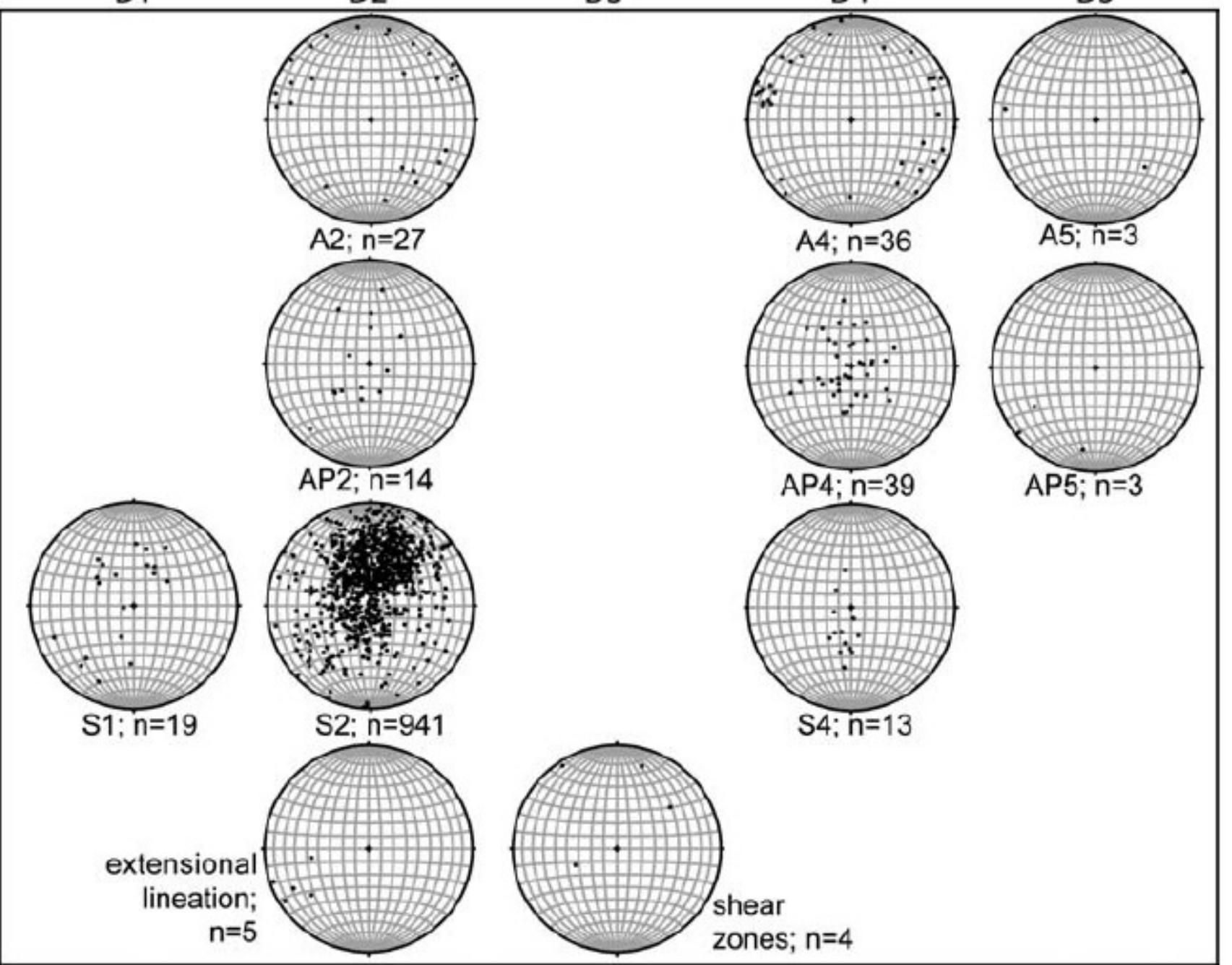




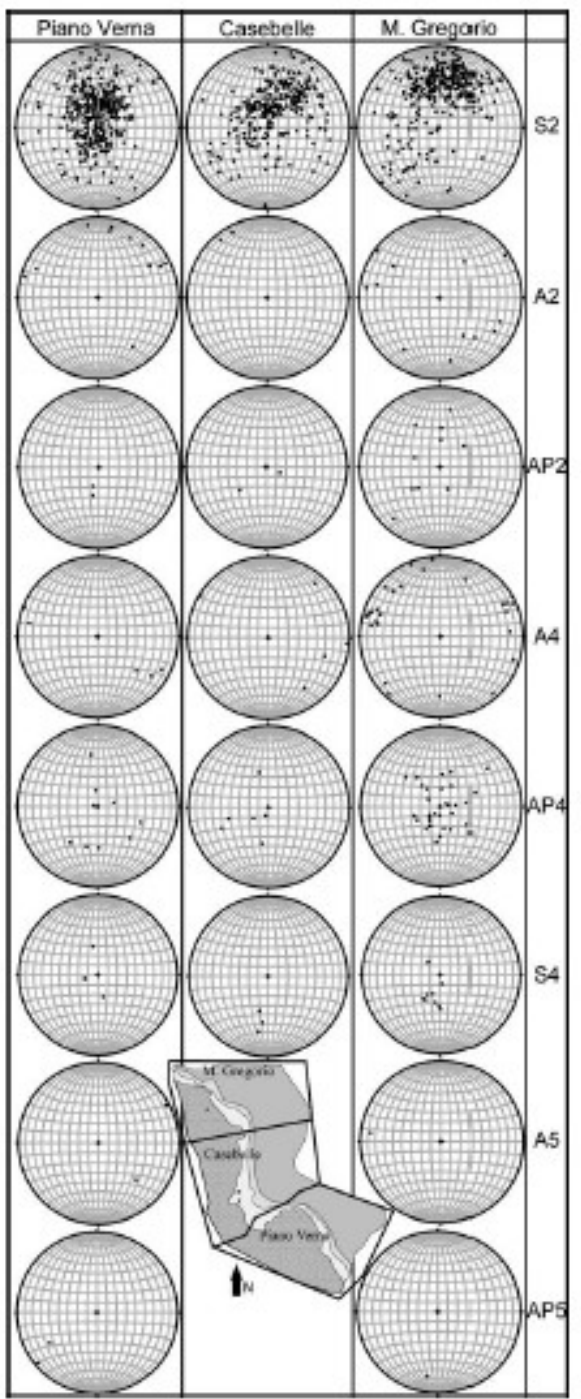





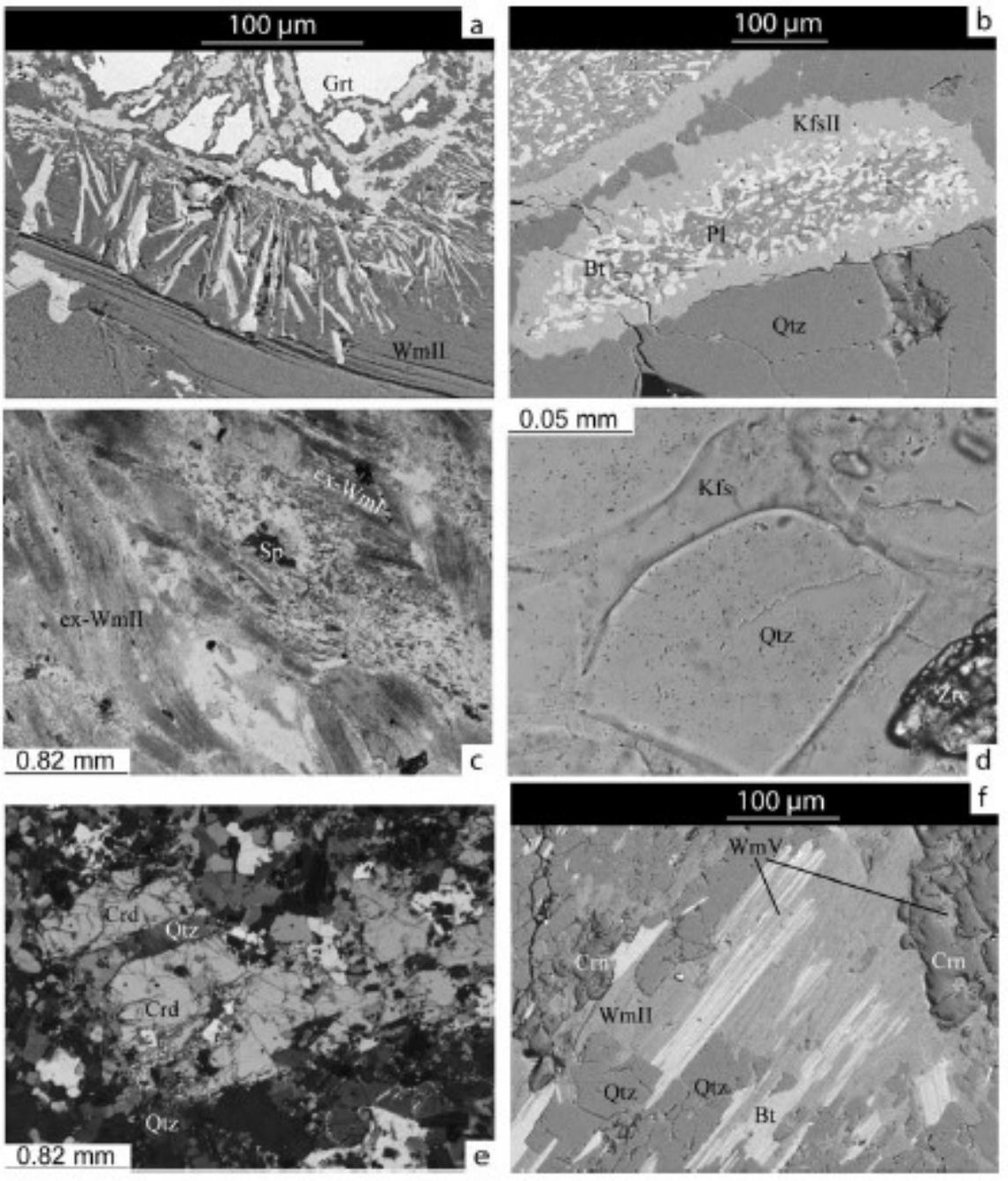




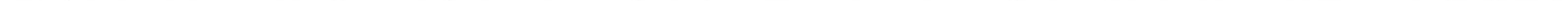


$O m p+W m=$

$\cdot A m p l+W m=A m p l l+B t+K f s$

$\mathrm{Grt}+\mathrm{Wm}=\mathrm{Pl}+\mathrm{Bt}$

$\mathrm{Rt}=\mathrm{IIm}$

$O m p+W m=B t+A b+Q t z \pm K f s$

Glf (or Na Ca Amp) $=A b+W m$

$E p=E p$ (REE)

$\mathrm{Grt}+\mathrm{Wm}_{\mathrm{m}}=\mathrm{Pl}+\mathrm{Bt} \pm \mathrm{CrC}$

$\mathrm{Wm}+\mathrm{Grt}=\mathrm{Bt}+\mathrm{Pl} \pm \mathrm{Crn} \pm \mathrm{Kfs}$

Glf $(\mathrm{oNa}$ Ca Amp) $+\mathrm{Wm}=\mathrm{Bt}+\mathrm{P}$

$\mathrm{Omp}+\mathrm{Wm}+\mathrm{Chl}=\mathrm{Bt}+\mathrm{Pl}+\mathrm{Otz}$

$\mathbf{W m}+\mathrm{Grt}=\mathrm{Bt}+\mathrm{PI}+\mathrm{Sp}+\mathrm{Crd}$ 

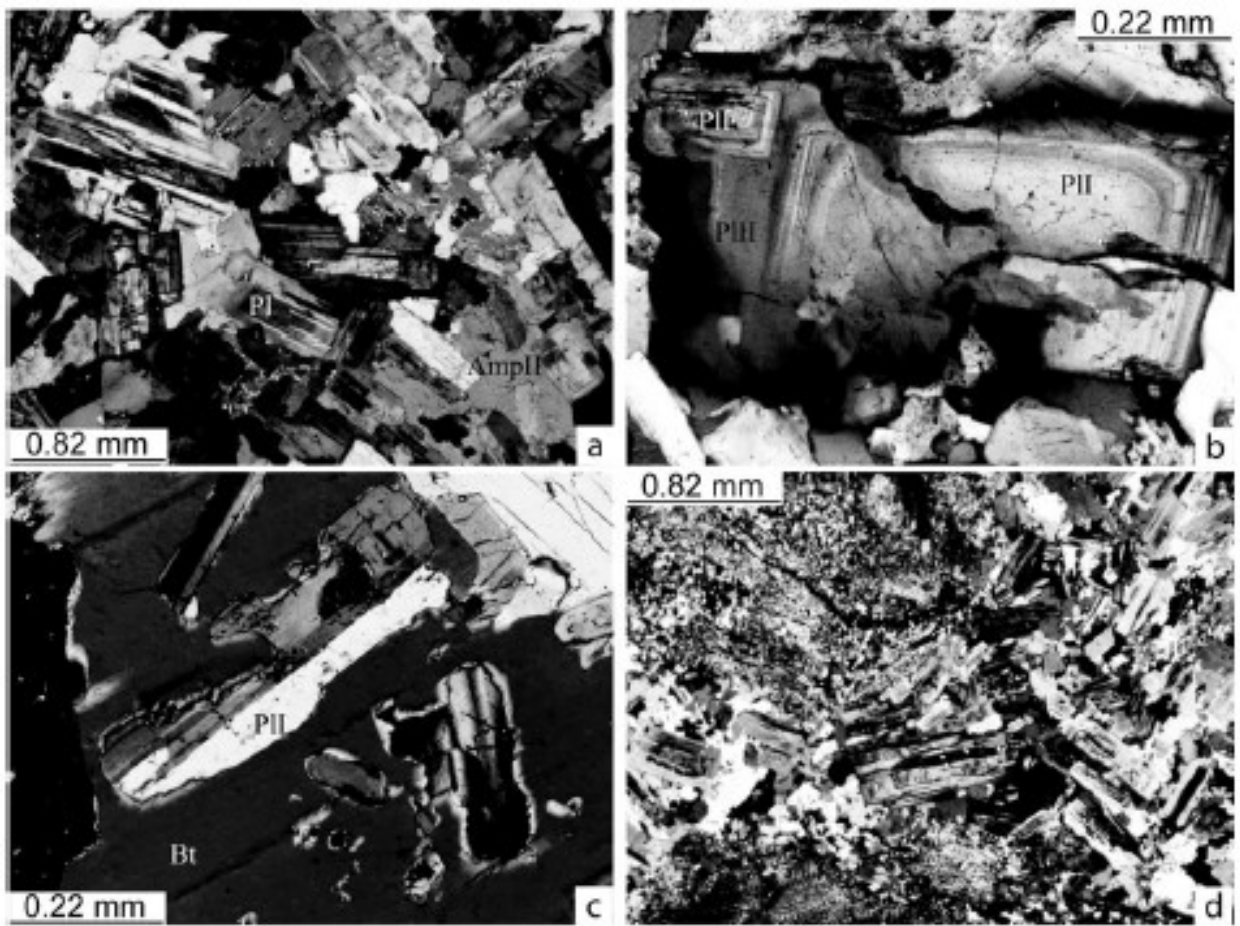

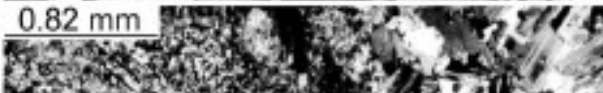

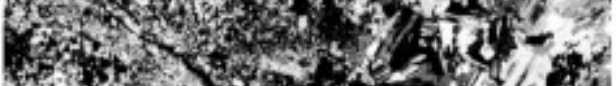

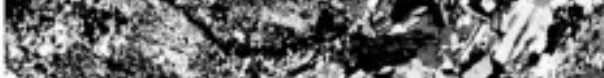

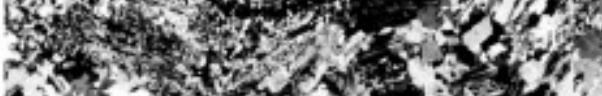

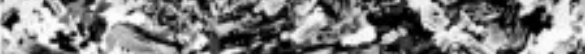

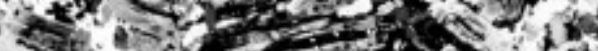

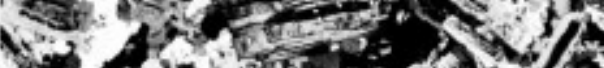

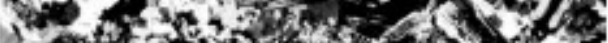

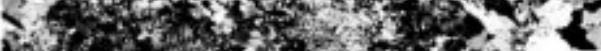

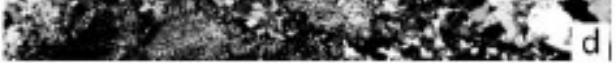

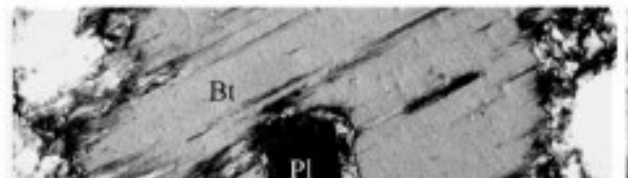

Q60.

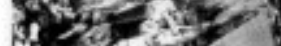
. ?

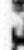
w. 25 D. neas. $0.22 \mathrm{~mm} \times$

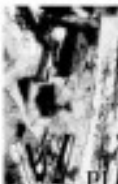

an as

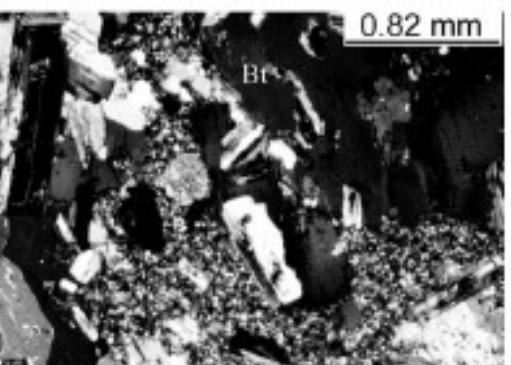

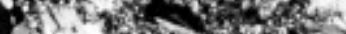

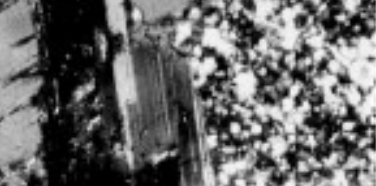
8 $1 x^{2}-3 x+2$ ivered e

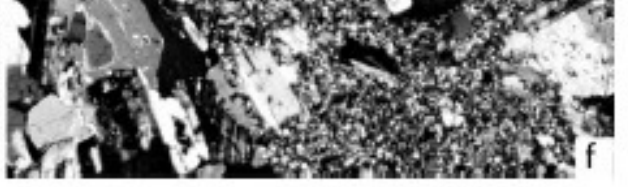

